\title{
The Settlement Patterns of Developed World Migrants in London
}

\author{
Paul White \\ [Paper received in final form, August 1997]
}

\begin{abstract}
Summary Contemporary international migration flows into European cities are now more diverse than used to be the case. The movement of less-skilled labour migrants has been replaced by the circulation of high-skill executives and specialist personnel involved in transnational corporations and in the financial services and other sectors affected by economic globalisation. To these are added other new service migrants and increased flows of students and independent young people. As a result, world cities are now witnessing the emergence of important categories of non-racialised international migrant groups. This paper considers whether such groups form distinctive residential concentrations in Greater London and uses the limited aggregate data available from the census to establish a general view of the geography of developed world migrants. There are important implications for urban theory and for discussions of urban ethnicity.
\end{abstract}

\section{Introduction}

The processes bringing international $\mathrm{mi}-$ grants to the bigger cities of Europe have until recently been seen as concerning very largely the well-documented flows of lessskilled labour migrants, and their families, drawn in during the boom period of postwar economic growth. A number of forces have operated to identify such migrants as 'others': legal controls; post-colonial sensibilities; social, religious and cultural distinctiveness; particular associations of employment sectors; racialisation; and segregated residential distributions that are in part the outcome of the operation of all these factors (Jackson, 1987).

Issues concerning the residential distributions and settlement patterns of these groups have been subjected to considerable ex- amination, and an extensive literature has been built up which has demonstrated elements of the distinctiveness of the European scene (in relation to the North American picture with which it has often been compared), and the importance of local, national or group-specific factors on particular outcomes (for international comparisons see, for example, Glebe and O'Loughlin, 1987; Espace, Populations, Sociétés, 1990; Huttman et al., 1991; Tijdschrift voor Economische en Sociale Geografie, 1997).

However, it has been clear for some time that the great wave of low-skilled labour migration, at least in northern Europe, has been replaced by a more complex pattern of international migration flows that relate to a number of changes in the contemporary 
world. The processes involved have been summed up as the 'globalisation' of international migration (Castles and Miller, 1993) or, in the case of Europe, as a 'postindustrial' migration wave (White, 1993). A number of elements make up this new pattern of migration flow. Considerable attention has been focused on flows of skilled workers, often moving within the internal labour markets of transnational corporations (Salt, 1988), particularly those operating in the financial services sectors (Beaverstock, 1991, 1994). Personnel transfers accompanying inward investment flows also play a role here (Cormode, 1994). These, however, are not the only contemporary flows affecting the major cities of the developed world that have in the past played host to earlier labour migrant arrivals and their families. In the late 1980s and the early 1990s, flows of asylumseekers added significantly to those arriving at the borders of a number of European countries, and although the number of claimants has now died down this is in part the result of major policy shifts in a number of potential destinations that have significantly changed the geopolitical dimensions of refugee movements (Collinson, 1996).

One aspect of the more informal development of open and integrated circulation spaces involving a number of countries (such as within the Schengen group) is the encouragement of a mentality of mobility on the part of some groups in society, such as students, which can lead to residential systems that may be transnational in scope, or which result in permanent movement for reasons of marriage or the setting up of a new household.

Much effort has been put into seeking to enumerate these various flows, and into considering their significance and potential future development at the national scale (Coleman, 1995; Kuijsten, 1994; Straubhaar, 1992). However, with few exceptions, such discussion has not considered the impacts of these new migration flows at the more regional or urban level. Yet these new migration systems are likely to be highly concentrated in their destinations, possibly even more so than with earlier waves of labour flows. The employing industries and service activities for those earlier flows were distributed throughout the manufacturing zones of the countries concerned. Today the forces likely to create the most substantial of the new flows relate most closely to opportunities within world cities, affected in a number of ways by globalisation trends. World or global cities are the ones most affected by the skilled labour transfers of transnational corporations (Beaverstock, 1996), whilst through the diverse changes resulting from economic restructuring they also, according to the thesis of Saskia Sassen (1991), offer opportunities for employment for clandestine migrants and others with only a tenuous link to traditional labour markets.

Past experience has shown that new migration flows generally create new social geographies in destination cities. Major migration flows in the earlier post-war period were predominantly composed of individuals and families whose choices of location were highly constrained by economic factors, as well as by regulatory activities by employers and by housing providers. Clearly there are still impoverished elements within the new flows described above (for example, students), but the significance of economic restrictions on residential choices is generally now much lower-particularly for those working in the higher echelons of transnational corporations. Here, however, residential search patterns may be highly conditioned by information offered to new arrivals through their employers or through particular agencies, such as relocation bureaux. Residential adjustment is important enough for a specific trade journal to have been set up in the UK- the Employee Relocation Journal-to discuss issues in personnel transfers. Different companies have different traditions involved in such transfers: Japanese companies in particular are distinctive with higher levels of employee rotations than have been common for other firms, with evidence from Germany suggesting that this in part brings about a very 
segregated pattern of Japanese residences, related to limited housing search with information controlled largely by the employer (Zielke, 1982; Glebe, 1986).

The objective of the current paper is to examine the residential distribution of certain new migrant groups in Greater London, with a view to analysing the impact of these groups on the social geography of the city. The paper seeks to determine the characteristics of the residential neighbourhoods affected by this new in-movement, and to suggest reasons for the localisation of particular groups in certain locations. Such an analysis enables the creation of new residential distributions to be put into the perspective of the experiences of segregation and concentration applying to the older minority communities derived essentially from labour migration flows of the past.

\section{Data Sources and Definitions}

The migration streams and the migrant communities that have been 'problematised' to date are principally those composed of labour flows. The greatest efforts at data collection have been aimed at such flows and their outcomes, and whilst registration systems and population censuses have generally taken some official interest in other migrants, aggregate tables of data have tended to ignore them altogether or have been very unspecific in terms of detailed attributes. This inevitably produces a severe limitation on what can be found out about them. In particular, in most European countries there are no cross-tabulations available to break down the identified populations by more detailed characteristics such as occupation, qualifications, household size and so on: the UK is not an exception in this. One obvious method of investigation would be to adopt a qualitative approach to the issues affecting and created by possible new migrant communities. However, ethnographies that might focus on known areas of residential concentration would lack the context of the more aggregate picture, whilst comparisons be- tween those of particular origins would be particularly difficult to achieve. Whilst recognising that one of the strengths of a qualitative approach would be the distinctiveness that could be identified between different migrants with apparently similar origins (for example, high-level executives, students or au pairs all from the same country), the approach adopted here is through the exploitation of the limited data available for London from the 1991 census to provide a general picture of the aggregate situation, and to raise specific questions for further future research. Many of the data used here, nevertheless, remain unpublished and were obtained from the computer database of the 'small area statistics' (SAS).

Discussions of the settlement patterns of migrant and ethnic minority communities in London have almost exclusively concentrated on New Commonwealth and Irish groups. Analysis making use of recent census information includes that by Robinson (1993), Peach (1996), Daley (this issue) and Phillips (this issue). A number of authors have used ethnographic, focus group or indepth interview techniques to raise questions of residence, belonging and experience (see, for example, Western, 1993; Mason, 1992). A particular focus of recent work has been on race equality issues in social housing, particularly in the light of privatisation trends (see, for example, Solomos, 1991; Peach and Byron, 1994). The focus of all these works, and many more, has been on London's 'racialised' minority populations. One other group that has been the subject of a number of research studies, using a variety of methods (although none from governmental statistics), is the Jewish population of the city (see, for example, Waterman and Kosmin, 1986), but the very few studies of nonracialised groups have been entirely based on qualitative research with small groups of respondents, such as in the work by Giles (1991) investigating gender issues among the Portuguese in the wealthy borough of Kensington and Chelsea (in the western inner city).

The racialisation of minority groups in 
British cities has predominantly concerned those originating in the New Commonwealth or, more widely, the Third World. 'White' populations have not been subject to this process, although the census categorisation of the Irish-born alongside the ethnic minority groups of the UK recognises a (contested) vernacular labelling of the Irish as a distinctive 'white' group. Certainly, the Irish have been traditional participants in labour migration to Great Britain, and especially to London (Chance, 1987), although the composition of the Irish migration stream has changed in recent years.

Two sets of questions in the 1991 British census enable the identification of 'other' populations. Unlike almost all other European countries, there was no census question on nationality. Instead, as has been the historic pattern throughout the post-war period, a question on country of birth was asked. In addition, following a trial in government surveys during the 1980s, a selfassignment question on ethnic group was also used in 1991, for the first time. The categories available for this latter question were: White, Black Caribbean, Black African, Black Other, Indian, Pakistani, Bangladeshi, Chinese, Other Asian, and Other. This ethnicity question has subsequently been seen as the more significant one for analytical research use.

The new migration streams that form the focus of the current paper originate in specific parts of the world, and are different in origin from the labour migrations of the past. The origins predominantly lie in Canada and the US in North America; in Australia and New Zealand; in Japan; in parts of the Middle East; and in the rest of Europe. To these might be added certain other specific origins for particular subgroups, such as the Philippines for domestic labour, or Malaysia, Hong Kong and Singapore for students.

However, the information available from the 1991 census has certain deficiencies for any attempt to deal with all these groups. The ethnicity variable can be discounted, since with few exceptions - the most important be- ing the Japanese, 87 per cent of whom were eventually classified as 'Other Asian', and those from the Middle East-the migrants under discussion very predominantly classified themselves as 'White'. This reinforces the suggestion that many of the new migrant communities in London are not potentially subject to the racialisation that has affected earlier migrants: the exceptions are the Japanese and Arabic populations.

The analysis that follows consists of a broad discussion of the residential distribution of a substantial group of London's immigrant residents, identified on the basis of their place of birth. The group consists of all those born in Canada, the US, Australia, New Zealand, and Europe with the exception of Ireland-a source of traditional labour flows to the UK. Left out of this group from those discussed above, therefore, are those with birthplaces in the Middle East (where the identification of exact country of origin in the census information is imprecise) and those born in Japan (who are introduced into the later analysis as a 'non-white' group). The group discussed here is therefore very predominantly of 'white' migrants from origins not traditionally associated with largescale labour migration: instead, their origins lie in areas of the world with levels of economic development similar to that of the UK.

It must, however, be noted that there are certain particularities attaching to those born in some countries. As a result of the stationing of large numbers of British forces personnel in that country after the Second World War, a considerable number of younger British residents were born in Germany but to service families: they would no doubt generally regard themselves as British despite their place of birth. In addition, amongst those born in Spain or Italy are included a number of older working-class migrants (most especially from Italy) as well as more recent high-skilled movers. Despite these conceptual problems, Germany, Spain and Italy were all kept in as relevant origins and to maintain the completeness of the general discussion of migrants from the developed world as a whole. 
Table 1. Growth of the most important birthplace groups from North America, Australasia and Europe (excluding Ireland) in London, 198191.

\begin{tabular}{lrrc}
\hline Birthplace & 1981 & 1991 & Percentage change \\
\hline USA & 22003 & 32667 & +48.5 \\
Australia & 16409 & 23315 & +42.1 \\
France & 13978 & 20923 & +49.7 \\
New Zealand & 10573 & 18379 & +73.8 \\
Portugal & 10872 & 13125 & +20.7 \\
Greece & 6083 & 7120 & +17.0 \\
Netherlands & 4643 & 5974 & +28.7 \\
Total & 241408 & 278715 & +15.5 \\
\hline
\end{tabular}

Note: criteria for inclusion: over 5000 present in 1991; and above average rate of growth 1981-91.

Sources: 1981 and 1991 Population Censuses of Great Britain, Country of Birth volumes.

Table 1 shows that the resident population of Greater London born in the countries defined for analysis rose by 15.5 per cent between 1981 and 1991. In contrast, the total population of Greater London rose by only 1.1 per cent. Clearly London had seen a considerable net immigration from abroad during the decade, with those from the countries labelled here as the sources of new migrants playing a full role in that growth. Indeed, given the fact that a proportion of the immigrant population recorded in 1981 would have died during the following 10 years, net in-movement must have been higher than that recorded in the table. It is also notable in relation to the discussion earlier in this paper that among many birthplace groups the predominance of London was extreme-suggesting that the association of new migration with the opportunities of a world city is a close one. Although Greater London in 1991 housed only 12.3 per cent of the population of Great Britain, it was the place of residence of 66 per cent of the population born in Portugal and now living in the country, with those born in Spain at 52 per cent, Greece at 50 per cent, Finland 39 per cent, New Zealand 37 per cent, and Austria and France both on 36 per cent.

It is difficult to use the census data to flesh out further details of the birthplace groups discussed so far. At the level of Greater London, the only additional data available relate to the sex ratio, whilst the limited information on employment and agestructure is available only at the scale of Great Britain as a whole. Nevertheless, there are indications of certain distinctive features within this sector of the population. Amongst all the birthplace groups, there is a predominance of women over men, in some cases with a striking sex ratio. Those with birthplaces in Europe display a particularly strong bias, commonly with ratios of only 50-60 males per 100 females: the most extreme case is that of those born in Finland, amongst whom the ratio was 28 males per 100 females. The most obvious explanation of these unusual sex ratios concerns the gendered nature of certain activities carried out in London by residents from these countries of origin. In particular, the employment of women as au pairs and the fact that more women than men come to Britain to learn or perfect their English both contribute to a pattern whereby women considerably outnumber men. The ratio was much closer to balance amongst those from more distant origins: between 75 and 85 males per 100 females in the cases of those born in the US, Canada, Australia or New Zealand. Data from the whole of Great Britain suggest that 
residents born in the countries dealt with here had variable activity rates, but those that were employed were notably concentrated in services; in Britain as a whole it was young adults who were most over represented amongst these groups, especially amongst women, which supports the explanations suggested above for unbalanced sex ratios.

The group of birthplaces chosen for analysis in Table 1, and retained for later consideration, was chosen on the basis of a definition of potentially non-racialised origins with little history of mass labour migration to Britain. One further birthplace group, however, merits discussion - those born in Japan. The development of this group in London has in many ways been more spectacular in recent years than has the growth of any other birthplace group. Between 1981 and 1991, the number of Japan-born residents of Greater London increased from 7964 to 17192 , or a growth rate of 115.9 per cent. In other respects, this Japan-born contingent fitted the characteristics of other nonEuropean groups, since the sex ratio was close to balance at 84 males per 100 females. The Japan-born provide a useful comparison with the other birthplace groups for whom there is generally far less cultural distinctiveness.

\section{The Geography of Settlement in London: Description}

As has already been indicated, few studies currently exist of the settlement patterns of non-racialised or developed world migrants in European cities, and those that have been published do not necessarily provide a good comparison with the case of London. The most important study to date has been that by Glebe on the Japanese in Düsseldorf (Glebe, 1986). Glebe showed the extreme segregation that existed amongst the migrant community, observing (p. 481) that they displayed 'the highest concentration and segregation of all minorities in Düsseldorf', with little sign of diffusion during the study period (1974-82). These are important findings, since they tend to contradict established views derived from the urban ecological tradition that the segregation of low-status migrants is partly a function of their class position, such that high-status migrants should be more spatially diffused in accordance with their more privileged position in the housing market. However, ethnic distinctiveness is still likely to play a potential role for Japanese residents in European cities.

In a study of the situation in Vienna, White (1988) showed that the relationships between skilled migrants and the housing market may be fairly specific. Where relatively short-term work placements are the norm, migrants may be confined to the private rented sector of the market. The properties that can be afforded may be at high rents within that sector, and the distribution of these will produce a series of locational constraints on the distribution of the group. The groups studied in Vienna principally covered high-status migrants drawn to work in international organisations. No differentiation between component groups within this highstatus sector was possible.

The only European city for which comparative work on different new migration groups has been carried out is Brussels (de Lannoy, 1975; van der Haegen, 1995). Both of these studies, separated by 20 years, examined the residential patterns of a number of foreigner groups in Brussels, drawn from a variety of origins. Segregation levels amongst the nonracialised groups from nearby countries (such as Britain or Germany) were shown to be as high as amongst those from, for example, Morocco or Turkey, but with very different residential areas being highlighted, particularly in the wealthier suburbs to the east and south of the city. With the exception of the French and Dutch, all high-status migrants were setting up residences in a society that was linguistically different, and van der Haegen observed the subsequent importance for suburban residential distributions of the location of suitable schools offering 'international' curricula or specialist teaching in the national education system of the migrants. 


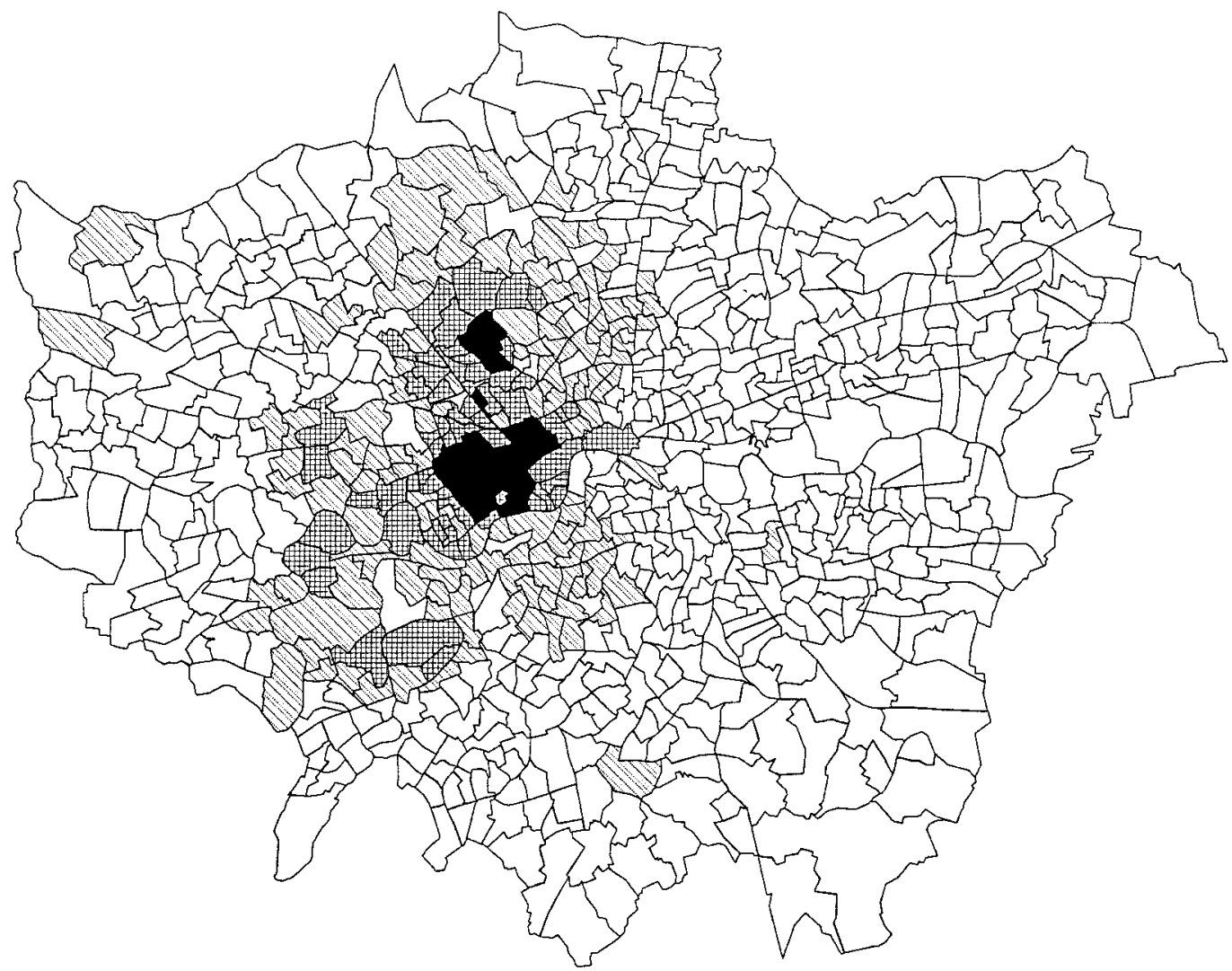

Less than 5 per cent

5-9.9 per cent

10-19.9 per cent

20 per cent and over (maximum 44.6 per cent)

$\vdash+1,+1,+1,+10 \mathrm{~km}$

Figure 1. Those born in North America, Australasia or Europe (excluding Ireland and the UK) as a percentage of the total population, 1991. Source: Census of Population 1991, unpublished country of birth tables. (Base map reproduced by permission of Crown copyright.)

Unlike the situation in Vienna or Brussels where much new migration relates to employment in the organs of the European Union, United Nations agencies or other international organisations, the research reported here on London therefore offers a case of new migration and settlement in a global city where circumstances are not primarily influenced by a small number of large organisations.
Figure 1 shows the distribution of the white migrant groups under discussion in Greater London in 1991, using 758 census districts (wards in each borough, but with the City of London taken as a single unit). In total, 4.2 per cent of Greater London's population was made up of those born in the countries identified here. It is very clear from Figure 1 that they are not evenly distributed throughout urban space. Three immediate 

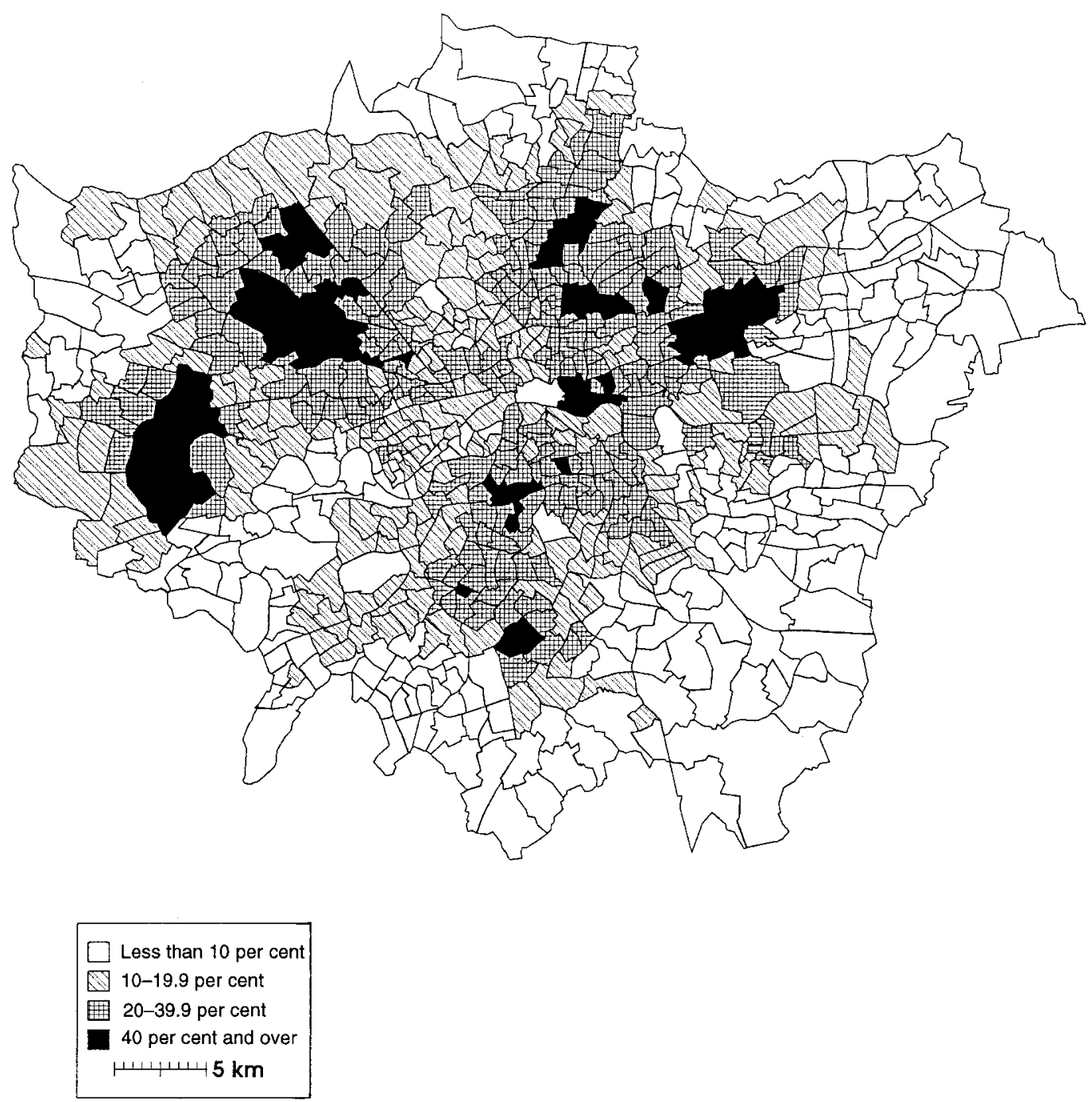

Figure 2. Those stating a non-white ethnicity as a percentage of the total population, 1991. Source: Census of Population 1991, unpublished ethnicity tables. (Base map reproduced by permission of Crown copyright.)

observations are possible. First, migrants from these European, North American and Australasian origins are virtually entirely absent from the whole of the eastern half of the city. Secondly, in the west of London there is a distinctly concentric pattern focused around a clear area of high levels of over-representation (in an area stretching from the West End of London westwards past Hyde Park and Knightsbridge to reach Earls Court and Kensington), with generally decreasing representation with increasing distance from this concentration. There is an outlier of this concentration area to the north, around Golders Green, with once again a distance-decay effect of reducing representation away from it. Thirdly, even in the west of the city, there is a general absence of migrants from these origins in outer suburban areas. The only significant exception occurs to the south-west of the main concentration zone where a sector with above- 
average representations spreads out through Richmond, Wimbledon and Kingston-highstatus residential areas of London.

There may be certain factors linking these three observations. One concerns the general image and reputation of areas. The residential areas of London that are more knownabout abroad may well be limited to the west of the city. In Kensington and surrounding areas in particular, a positive image of wealth and cosmopolitan identity is reinforced by the presence of a large number of hotels at which many foreigners stay during their first visit to London, and by the nearby location of many foreign embassies and consulates. Processes of 'learning about' a city may be crucially important in influencing later information availability and residential decisionmaking.

The pattern shown in Figure 1, showing the residential locations of a very predominantly white migrant group in Greater London, is very markedly different from that of the racialised minorities of the city. Because a high proportion of such ethnic minorities had been born in the UK, the definition used here is that from the ethnicity question of the 1991 census, therefore identifying all those who indicated a non-white ethnicity. It must be accepted that there will be certain overlaps between the populations dealt with in Figures 1 and 2 (for example, of AfroAmericans born in the US who gave one of the 'Black' categories as their ethnicity in the census), but in relation to the total sizes of the populations under discussion these overlaps are likely to be small. In 1991, 1.3 million of London's residents indicated a non-white ethnicity (or 20.15 per cent of the total population).

The distribution on non-white ethnicities (Figure 2) is different from the distribution of the predominantly white immigrant groups (Figure 1) in a number of respects. First the representations of non-whites are below the city-wide average in many parts of the inner city, and particularly in those wards that had high proportions of white immigrants in Figure 1. In the main concentration areas of Figure 1, the immigrants from North Amer- ica, Australasia and Europe are actually more numerous than those who claim an ethnic minority identity. Secondly, the concentrations of non-white ethnicities occur much more strongly in certain middle-distance suburbs, but there is a pattern of considerable fragmentation, with a number of separate concentration areas. These are, in fact, composed of different minority groups, with the westernmost concentration area being composed of Indians and the areas to the northwest and north of the city centre having high proportions of both Indians and various Black groups (see also Daley in this issue). Indians are again the predominant minority group in the eastern concentration area, with a small area of Bangladeshi concentration immediately to the east of the city centre, on the edge of Docklands.

A third observation from Figure 2 is that London's ethnic minority populations, unlike the predominantly white immigrants, are present in the east as well as the west of the city. However, one point of similarity between the two distributions is the generally belowaverage representation in the outer suburban areas.

The Japan-born have been described aboveas a separate group, with a distinctive ethnic identity but also with compositional characteristics that are shared with the other developed world immigrant groups. Those Japan-born who identified themselves as non-white (the vast majority) are included in the data in Figure 2. However, it is instructive to separate them out for individual consideration. Figure 3 shows the distribution of the Japan-born in 1991. Across London as a whole 0.25 per cent of the population was born in Japan (or 1 person in 400), but a maximum concentration level of 7.68 per cent ( 1 person in 13) was reached in one ward of north London. As Figure 3 makes clear, the distribution of the Japan-born was distinctive from both that of the immigrant groups from North America, Australasia and Europe, and that of those stating a non-white ethnicity. Certainly there was some evidence of Japan-born concentrations in inner west London (particularly Kensington) and in 


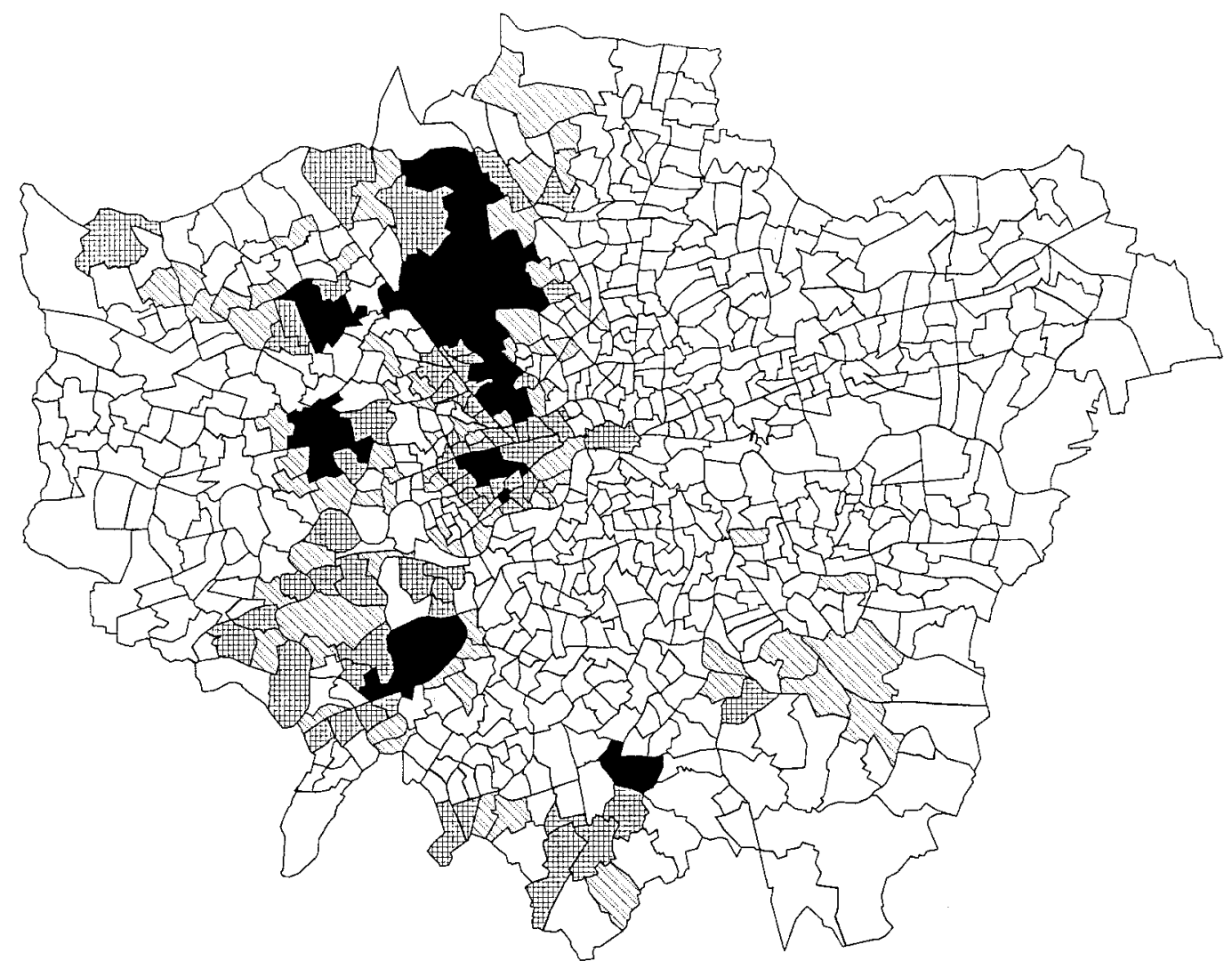

Figure 3. Those born in Japan as a percentage of the total population, 1991. Source: Census of Population 1991, data extracted from the unpublished small area statistics files. (Base map reproduced by permission of Crown copyright.)

Golders Green in north London, as with the predominantly white migrants in Figure 1. But the main concentration area of the Japanborn lay in a wider northern sector of London, and in a small outlier to the west of this, with another area of concentration to the west of the city in the borough of Ealing. There were also patches of higher representation in south-west and south London, where the alignment of such wards along commuter railway lines is discernible. In these south- west London areas, there is a relationship between the presence of the Japan-born and a certain over-representation of the white immigrant groups in the higher-status wards of Richmond, Wimbledon and Kingston identified above. The comparison of Figures 2 and 3 shows that - apart from a very small number of wards in north-west London-the main areas of Japan-born concentration are separate from those of the self-designated ethnic minority population as a whole. 

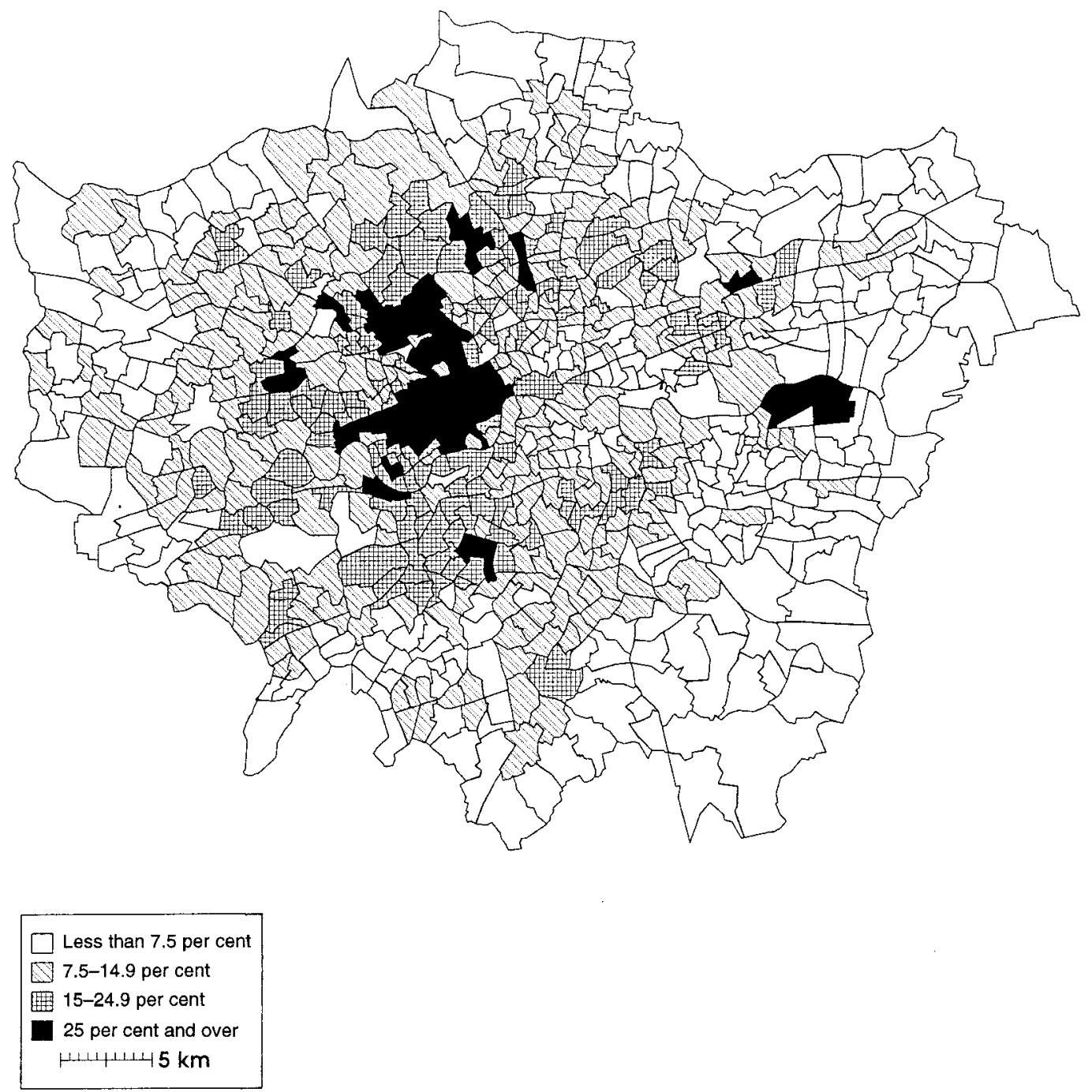

Figure 4. Households in private rented property as a percentage of all households, 1991. Source: Census of Population 1991, unpublished housing tenure tables. (Base map reproduced by permission of Crown copyright.)

The Geography of Settlement in London: Explanations

The mapped distributions of developed world migrants in Figures 1 and 3, and their distinctive differences from the distribution of ethnic minority groups in Figure 2, show the existence of a specific social geography of developed world migrant destinations in Greater London. This geography can be related to a number of characteristics of the built and social environment as a means of leading to suggested explanations.

In the housing environment of London, an important distinction is that the eastern half of Greater London has the greater predominance of council housing, whilst the west has the greater availability of property available for private renting. In many wards in the eastern inner suburbs, and immediately south of the River Thames opposite the City of London, well over half of all residential property was in local authority tenures in 1991, with a maximum of 86 per cent in one ward. To the west, less than 10 wards had the majority of their housing in council control. Conversely, as Figure 4 shows, the main 
areas of private rented property lay in the west of London, with particular concentrations in the areas picked out in Figure 1 as having above-average representations of the predominantly white immigrant groups. This particularly applied in Kensington and surrounding areas, with high proportions of private rented properties also occurring in the northern sector of the city, coincident both with the distribution shown in Figure 1 and with that of the Japan-born in Figure 3 . However, the coincidence between the distribution of immigrants from North America, Australasia, Europe and Japan and areas with private rented property breaks down in certain other parts of London, particularly in those areas of the east where private rented properties are present, but where the immigrants under discussion are not. The dominance of the Kensington area for these migrants (Figure 1) may well be related to the fact that it is the area of private rented property with the easiest access to London Heathrow airport. Other areas, particularly in the east of the city, lack such access.

In socioeconomic status terms, the contrast between east and west London is also clear, and again shows relationships to the distribution of the immigrant groups under consideration. Figure 5 maps the proportions of the economically active population who were classed as being in social groups $\mathrm{A}, \mathrm{B}$ or $\mathrm{C} 1$ in the 1991 census. These groups consist of those employed in the liberal professions, or in executive and management positions (labelled 'intermediate occupations') and in skilled non-manual sectors. At the centre of Greater London, the City of London itself stands out. The general pattern is strongly sectoral with a number of outliers. One sector runs out to the north in an almostcontinuous belt of wards with over 50 per cent representation stretching from Hyde Park to the fringes of Hertfordshire and the Green Belt. The other sector runs out through Kensington through a number of areas of south-west London but with a number of gaps, these being predominantly wards with some local authority properties. Interestingly, these two sectors pivot on the West End of
London, rather than on the City itself. Apart from these sectors, there was some dispersion of social classes $\mathrm{A}, \mathrm{B}$ and $\mathrm{C} 1$ in other parts of Greater London, including some areas of east London (particularly in the south-eastern suburbs). However, the east generally had many more wards with marked under-representation of these socioeconomic groups. In west London, only 40 wards scored less than 50 per cent on this variable, and in half of these cases they also had over 40 per cent of their populations drawn from ethnic minorities. In east London, this association was absent: amongst the many wards with low proportions of the white-collar socioeconomic groups, some had significant ethnic minority populations whilst a large number of others were almost entirely 'white'.

These discussions of housing and social distributions in London draw out a number of relationships with the pattern of predominantly white immigrant settlement, and a number of reasons can be put forward for this. In terms of housing structures, the reasons for the presence of North American, Australasian and European migrants (and even more so the Japan-born) need to be born in mind. As suggested earlier in this paper, a significant motivation for movement to London commonly relates to movement within transnational corporations, and such moves are commonly relatively short-term in nature before another posting elsewhere. Amongst the major sources of foreign direct investment in Britain today, the US, Germany, France and Japan stand out, and the significance of these countries is particularly great in financial services in the City of London. Those involved in temporary stays in a 'host' city are more likely to seek privately rented property than to move into owner-occupation where transactions costs are high relative to the period of occupation. A positive relationship between such migrants and areas of privately rented property may therefore be expected, with the attractions of furnished property possibly being greater than those of unfurnished. Given the ways in which corporations, through relo- 

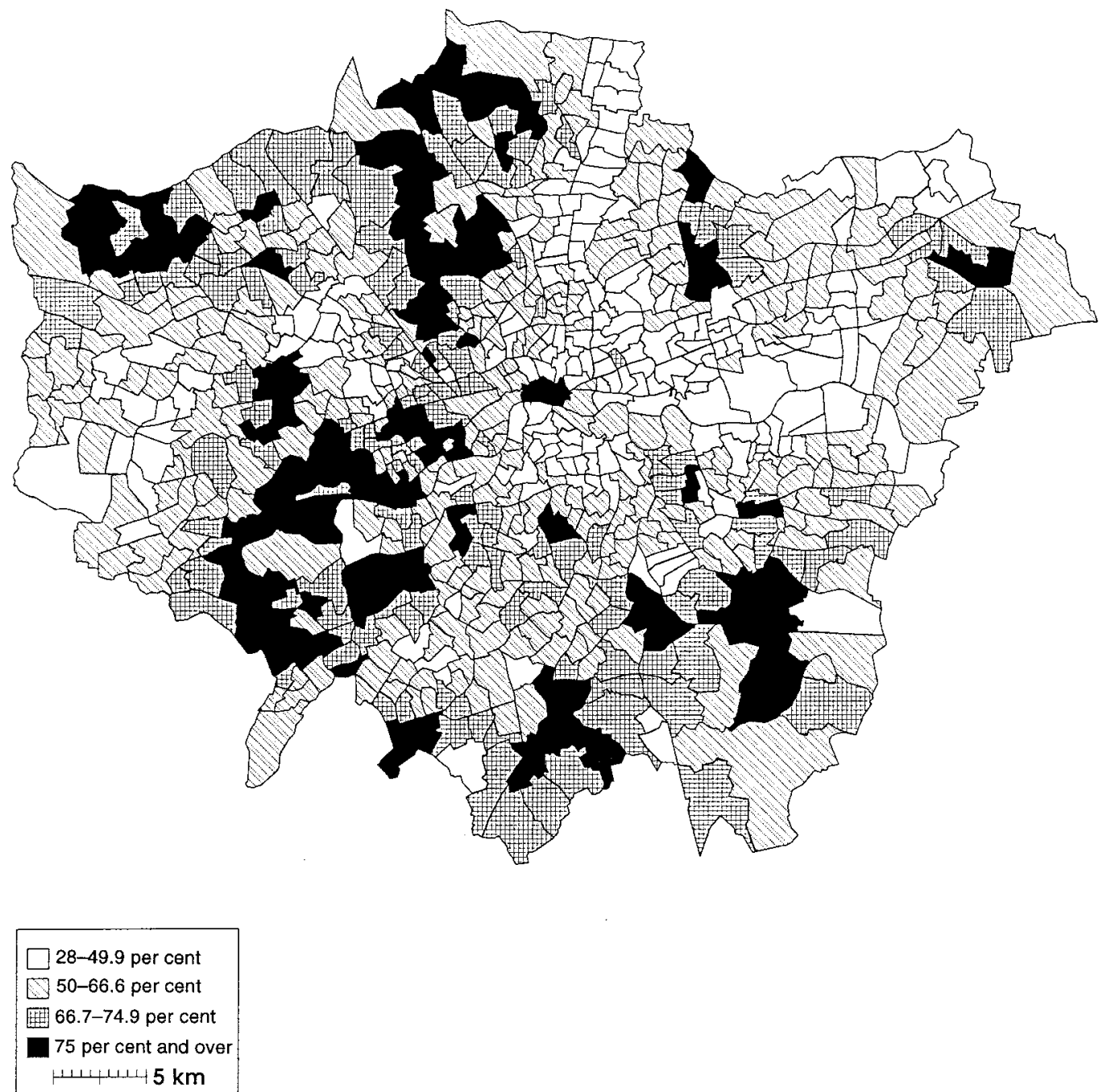

Figure 5. Economically active population in socioeconomic groups A, B or C1 (professional, managerial and intermediate occupations, skilled non-manual) as a percentage of all those economically active. Source: Census of Population 1991, unpublished socioeconomic group data. (Base map reproduced by permission of Crown copyright.)

cation packages, try to smooth the moves of their employees, it is also possible that there may be particular concentrations of migrants in areas where property is rented as part of the job. Because privately rented property in London is more often in blocks of flats than in houses (terraced, semi-detached or detached), a positive relationship between $\mathrm{mi}-$ grant settlement and areas of apartments might be expected. It was indicated earlier that a specific sector of the migrant groups under discussion here consists of students, and particularly of language students. For these individuals, the private renting of property is almost inevitably the only housing opportunity open to them.

Apart from an expected negative relationship between the migrants under discussion here and the existence of owner-occupied property, it would also be expected that there would be a negative relationship with areas of local authority housing. This would occur 
partly because such areas would characteristically be working-class in nature, but also because the predominantly white migrant groups would lack the access criteria to such property.

In socioeconomic terms, it is clear that many of the corporate migrants are likely to be of high skill levels or to be working in managerial occupations. Given the possible limitations of such migrants to private rented sectors of the housing market, however, it is not clear that their distribution will mirror that of all Londoners in similar occupations. Much thinking derived from traditional approaches to urban social segregation has suggested that amongst migrants without the possibility of racialisation, segregation levels should be lower since the groups should reproduce the residential distributions of the indigenous population. However, it has been suggested above that this may not occur because of housing market factors affecting the choice of property made by the migrants. On the other hand, it needs to be observed that amongst one section of the migrant groups considered here - that of au pairs - there is almost certain to be a strong relationship to the wider distribution of high-earning groups in the city who can afford, and need, their services.

The fragmentation of the motivations among the migrants under consideration potentially produces contradictory possibilities over demographic associations. Many of the migrants, particularly from the Old Commonwealth (and especially from Australia or New Zealand) are students or recent graduates, living non-familial lifestyles. However, a number of international executives are accompanied by their families, while au pairs are inevitably drawn to families with young children. The relationships between the distribution of the predominantly white migrant groups and the familial geography of London are thus likely to be complex.

A final suggestion can be made concerning the likelihood of a strong relationship between the representation of the migrant groups and the level of population turnover.

The examination of these possible rela- tionships is made harder by the limitations of the data available. With few detailed characteristics of birthplace groups available from the census, the approach adopted here is the relatively crude method of ecological correlation, relating the spatial distribution of the migrant group as a whole to the geography of a number of other variables. The dangers of the ecological fallacy need to be born in mind throughout: the relationships only show associations between spatial patterns rather than indicating that particular characteristics necessarily apply to the migrant groups considered.

Table 2 shows the correlation coefficients between a number of indicator variables and the percentage of residents that consists of those born in North America, Australasia and Europe excluding Ireland. Many of the findings uphold the suggestions made above concerning the probable direction of relationships. In particular, the strongest relationships in the table link migrant representation to the proportion of privately rented property, especially that which is rented furnished. A further important housing relationship concerns the proportion of property rented as part of a job or business. These correlations indicate the clustering of the predominantly white immigrant groups in areas of London where access to property, through the private rented market, is easy and, in some cases, available via employers. The relationships with the distribution of owner-occupied or local authority housing, whilst negative as expected, are lower in strength, and act as a reminder of the fact that even where private rented property is at its maximum in the city (as in the Kensington area) there are still considerable proportions of owner-occupied housing. In terms of dwelling type, Table 2 indicates the mild positive relationship with areas of apartment blocks, and the negative associations with houses, whether detached, semi-detached or terraced.

The relationships with socioeconomic data suggest two interesting findings. First, the migrants dealt with here from North America, Australasia and Europe (excluding Ireland) are strongly associated with those areas 
Table 2. Ecological correlations of birthplace group concentrations, 1991: correlation coefficients between percentages of ward populations of group $x$ and other variables $(n=758)$

North America,

Australasia,

Europe (excluding

Birthplace

UK and Ireland)

France

Australia

Japan

Housing

Private rented households as a

$\begin{array}{llll}+0.81 & +0.70 & +0.80 & +0.42 \\ +0.81 & +0.70 & +0.80 & +0.45 \\ +0.64 & +0.53 & +0.62 & +0.28 \\ -0.24 & -0.20 & -0.25 & +0.02 \\ +0.52 & +0.43 & +0.43 & +0.21 \\ -0.20 & -0.18 & -0.18 & -0.23 \\ -0.28 & -0.25 & -0.32 & +0.05 \\ -0.37 & -0.28 & -0.35 & -0.29 \\ +0.16 & +0.10 & +0.16 & +0.05\end{array}$

percentage of all households

Rented furnished

Rented unfurnished

Owner-occupied households as

a percentage of all households

Renting property as part of a

job as a percentage of all households

Local authority renting as a percentage of

all households

Detached or semi-detached

dwellings as a percentage of all dwellings

Terraced dwellings as a

percentage of all dwellings

Flats in residential buildings as

a percentage of all dwellings

Socio-demographic

Percentage of households containing a

family_parent(s) with child(ren)

$-0.54$

$-0.67$

$-0.24$

Socio-economic

Percentage of population aged $16+$

employed in banking and finance

Percentage of employed males working

in three high-skill occupations ${ }^{\mathrm{a}}$

Percentage of employed females

working in three high-skill

occupations $^{\mathrm{a}}$

Percentage of active male population in social classes A, B or C1

Percentage of active female population

in social classes $\mathrm{A}, \mathrm{B}$ or $\mathrm{C} 1$

\section{Migration}

Percentage of population employed in three

high-skill sectors ${ }^{\mathrm{b}}$ who moved

in the year prior to the census

$\begin{array}{llll}+0.57 & +0.53 & +0.61 & +0.36 \\ +0.62 & +0.52 & +0.62 & +0.46 \\ +0.57 & +0.46 & +0.61 & +0.39 \\ +0.53 & +0.45 & +0.53 & +0.45 \\ +0.18 & +0.15 & +0.22 & +0.26 \\ +0.47 & & & \\ & +0.39 & +0.48 & +0.38\end{array}$

\footnotetext{
${ }^{a}$ Managers/administrators; professional occupations; associate professional and technical occupations.

b Managers in large establishments; managers in small establishments; professional workers (employees).

Source: 1991 Population Census of Great Britain, various tables and the unpublished small area statistics files.
}

of London characterised by residents employed in financial services, in managerial and skilled positions more generally, and with the upper socioeconomic status groups.
The second finding, however, is that there is a gender issue in this relationship, since the associations with high-status female employment are lower than with male. The same is 
true of the migration variable, where the presence of the migrant group is clearly related to high turnover levels amongst the more skilled, but with that relationship being stronger with turnover among the male skilled $(+0.48)$ than among skilled females $(+0.28)$.

There are clear indications here, therefore, that, as expected from the earlier discussion, the settlement of migrants from North America, Australasia and other parts of Europe has tended to occur most strongly in those parts of London with the highest occupational status. However, the correlation coefficients are held down because of the concentration of the migrant groups in areas of rented property. Elsewhere in London, high socioeconomic status and owner-occupation go hand in hand: for the predominantly white migrant group the status-housing link occurs via the limited areas of the city in which high-quality private rented property is available.

It was suggested at the start of this paper that the motivations for movement to London may in fact be quite varied, and that this fact may yield somewhat different settlement patterns amongst individual birthplace groups or sub-sectors of them. Table 2 allows some consideration of this suggestion by focusing on two birthplace groups drawn from the overall predominantly white group, as well as by considering separately the case of those born in Japan. Those born in France are considered as an example of a potentially very mixed group of residents but one where certain cultural distinctions, particularly over language, may play a role. Those born in Australia are known to include a high number of young people in non-familial situations: cultural distinctions from English society are also relatively weak. The Japanborn are still predominantly related to corporate moves, although with some student presences, and are excluded from the initial group dealt with in Table 2 on the grounds of their ethnic distinctiveness.

Of these groups, Table 2 shows that the position of the Japan-born is the most striking. The relationship with areas of rented property is much weaker than for the larger predominantly white group, and there are actually slight positive relationships with areas of owner-occupation and of detached or semi-detached houses. The relationships with areas housing those in higher-status occupations are, again, generally weaker than for the white immigrant group, except for the variable concerning women classed as being in socioeconomic groups $\mathrm{A}, \mathrm{B}$ or $\mathrm{C} 1$. The distribution of the Japan-born in London is less clearly 'explained' by the examination of contextual ecological factors than is that of the other groups considered. Both those born in Australia and those born in France generally 'fit' the overall pattern of the whole group from which they were here extracted, and to an extent that indicates that this is not a statistical artefact relating to their proportional contribution to that group.

There are, however, certain differences between the France- and the Australia-born. In particular, the housing relationships of those from Australia are generally clearer, as also are the links to socioeconomic variables. One point of interest relates to the relationship of all the groups in Table 2 to the presence of familial households. The correlation coefficients for all groups are negative, but with that for the Australia-born being particularly high. On the other hand, that for the Japan-born is much lower, indicating that they are not repelled to the same extent from those areas of London that have a more familial characteristic. Such an observation clearly ties in with the finding from Figure 3 that the distribution of the Japanborn is more suburban than is the norm for the other migrant groups dealt with in this study.

It follows from this discussion of the ecological links of specific groups defined by birthplace that the degrees of residential concentration of different groups may vary. Calculation of the indices of segregation (IS) for the three single-birthplace groups in Table 2 shows this indeed to be the case. Amongst these, the Japan-born have an index of 61.8, whilst that of the Australia-born is 40.2 and of those born in France 39.7. Peach (1996), 
using the ethnicity data from the census, calculated the highest IS of a group identified in that way as 63 for the Bangladeshis, with only the Chinese (on 26) having an index lower than that applying to those born in Australia or France. This finding on the high segregation level of the Japan-born in London matches with Glebe's (1986) finding in Düsseldorf that they were the most segregated group in that city, and with evidence from Brussels (van de Haegen, 1995). It is also of interest that the France-born and the Australia-born, with low ethnic distinctiveness, actually display such high levels of segregation.

\section{Discussion}

Data presented in this paper have provided a first tentative consideration of the growth and distribution of certain previously unexamined migrant groups in Greater London. It is clear that in recent years an important contribution to the population of the city has come from the migration of those born in countries with a similar level of economic development to that of the UK itself. Whereas in the past the most significant migration flows, both in terms of their numerical size and in terms of their social impact, have predominantly been from countries of the New Commonwealth, and from Ireland, the emerging patterns of the late 20th century show the growing significance of a new range of $\mathrm{mi-}$ grant origins. The opportunities offered by a world city are many and varied, and these new migration flows can be understood in the context of discussions of globalisation in the economic sphere (Sassen, 1991), alongside the progressive development of a wider international labour market within the European Union and the increasing global circulation of specific sub-populations such as students.

Whilst the longer-standing migration systems and their resultant communities have been the subject of much academic research, these new flows have not so far been examined in this way. Nevertheless, the investigation of their form and impact has a number of contributions to make. First, it can be sug- gested that such flows have become an established part of the scene in certain global cities such as London (or Paris, or New York), and that in the case of London they are likely to increase for two specific reasons-the continued freeing-up of labour flows in the European Union through increased recognition of qualifications, and the position of London as one of the principal cities using the most significant language for world communications, English. There is a contemporary, and probable future, significance in such flows and their outcomes that merits monitoring.

A second reason for studying these new migrant communities concerns the role that such discussion may have for theories of urban ethnicity and the roles of ethnic communities. In the case of London, ethnicity clearly plays a role amongst the new migration streams such that class and economic relationships are not the sole determinant of residential distributions. This is very clearly so amongst the Japan-born, where levels of urban segregation closely resemble those applying to the most deprived of London's minorities. Relative wealth, qualifications and high skilled employment do not necessarily bring residential dispersion. There are good reasons for this in the context of more circulatory migration systems than have occurred in the past, especially where those involved in such circulation demand high levels of specific service provision that is often capital intensive. Circulating migrants may not wish to integrate fully into the social, cultural and institutional life of their destinations, where the length of stay is indeterminate but unlikely to be permanent. The creation of separate institutions by and for the migrant group may initially reflect certain aspects of their distribution, but may then come to play a determining role in the preferred locations of future arrivals.

This can be briefly illustrated by the cases of 'Japanese' and 'French' facilities in London. London's principal Japanese school is located within one of the residential concentration areas of north and west London indicated on Figure 3. Nearby are a wide variety 
of other services marketed specifically to a Japanese population-including food shops, hairdressers, opticians and, significantly, estate agencies. The Kensington cluster of the Japan-born does not have a school but has a wide variety of these other facilities. The Wimbledon cluster in south-west London has no school, and fewer facilities than elsewhere: however another Japanese school of the London area (in Surrey, just outside the Greater London boundary) is on a direct railway line from Wimbledon. In the case of 'French' facilities, the main 'Lycée Française' is in South Kensington, on the edge of a census ward where just over 7 per cent of the residential population in 1991 had been born in France: the area also has a wide variety of other French services, such as food shops, lawyers and bookshops, such that local people have adopted the area title 'Frog Valley' (by analogy with the nearby 'Kangaroo Valley' of Australians in Earls Court).

Clearly where there are strong community infrastructures of these kinds there are reasons for the perpetuation and accentuation of areas of residential concentration. The significance of schools can be stressed (and certainly most of the specialist 'foreign' schools in London, including the German, American and Swedish schools, are located in the west), but two other factors need to be born in mind: the evidence suggests that many of the new migrant groups are not strongly familial, and the segregation level of those born in Australia (for whom no local schooling infrastructure exists) is identical to that of the French-born (for many of whom the Lycée Française is an important facility). Consideration of the settlement patterns of new and generally unracialised migrant groups re-opens older questions about voluntary segregation and desires for in-group orientation, in situations where other opportunities may be present. In this respect the generally lower correlations between the distribution of the Japan-born and elements of the housing and socio-economic environment, coupled with their high level of segregation, may suggest that the particular locational factor for new Japan-born migrants is the presence of an existing Japanese community.

A third major interest in these new migrant groups, however, lies in the issues they raise concerning the relationships between migrants and the housing market. It has been common experience throughout Europe and elsewhere that the primary housing sector for newly arriving migrants has been that of privately rented accommodation (White, 1984). For past labour migration streams the reasons for that involved both cost and access, and the property rented was of poor quality. Whilst the evidence presented in this paper does not affirm that the new migrant groups are concentrated in private rented accommodation, the ecological and circumstantial evidence for such an over-representation is strong. The reasons today relate to temporary time-horizons. However, this housing market sector is today much smaller than it was in the past: between 1981 and 1991 the absolute number of private rented units in Greater London declined by 10.9 per cent against a general growth in housing units of 10.2 per cent. By 1991 the private rented sector formed only 12.2 per cent of the total housing market. With likely increases in circulatory migration in the future it will be interesting to see the extent to which the private rented housing sector becomes a segregated one dominated by short-term foreignborn migrants. Such developments would require a re-evaluation of existing theories of interactions between migrants and housing markets.

This paper has shown that there is clearly a very distinctive social geography within London associated with developed world migrant groups who are currently growing in number and importance. The initial study here, however, has remained at an aggregate level, exploiting the very limited data that are currently available, but providing a general overview of a largely undocumented phenomenon. It raises a number of questions that require further research. Exploitation of the anonymised records from the 1991 census (which permit the derivation of further 
cross-tabulations) is unlikely to be very fruitful: with its 1 per cent sample basis, discussion of even the Japan-born or Franceborn would have only about 150 respondents with no meaningful possibility of employing any spatial breakdowns. Instead the way forward for the examination of some of the important issues concerning residential search behaviour, the importance of groupspecific information flows, and the segmentation of particular groups, lies in a more ethnographic approach, set within the context of the more general patterns described here.

\section{References}

BeAverstock, J. V. (1991) Skilled international labour migration: an analysis of the geography of international secondments within large accountancy firms, Environment and Planning A, 23, pp. 1133-1146.

BEAVERSTOCK, J. V. (1994) Re-thinking skilled international labour migration: world cities and banking organisations, Geoforum, 25, pp. 323328.

BeAVERstock, J. V. (1996) Revisiting high-waged labour market demand in global cities: British professional and managerial workers in New York City, International Journal of Urban and Regional Research, 20, pp. 422-445.

Castles, S. and Miller, M. J. (1993) The Age of Migration: International Population Movements in the Modern World. London: Macmillan.

Chance, J. (1987) The Irish in London: an exploration of ethnic boundary maintenance, in: P. JACKSON (Ed.) Race and Racism: Essays in Social Geography, pp. 142-160. London: Allen and Unwin.

Coleman, D. (1995) International migration: demographic and socioeconomic consequences in the United Kingdom and Europe, International Migration Review, 29, pp. 155-206.

Collinson, S. (1996) Visa requirements, carrier sanctions, 'safe third countries' and 'readmission': the development of an asylum 'buffer zone' in Europe, Transactions, Institute of British Geographers, 21, pp. 76-90.

Cormode, L. (1994) Japanese foreign direct investment and the circulation of personnel from Japan to Canada, in: W. T. S. Gould and A. M. FIndlay (Eds) Population Migration and the Changing World Order, pp. 67-90. Chichester: Wiley.

Espace, Populations, Sociétiés (1990) Les Communautés Etrangères en Europe/Foreign Communities in Europe, theme issue, 1990-2.
GiLes, W. (1991) Class, gender and race struggles in a Portuguese neighbourhood in London, International Journal of Urban and Regional Research, 15, pp. 432-441.

Glebe, G. (1986) Segregation and intra-urban mobility of a high-status ethnic group: the case of the Japanese in Düsseldorf, Ethnic and Racial Studies, 9, pp. 461-483.

Glebe, G. and O'Loughlin, J. (Eds) (1987) Foreign Minorities in Continental European Cities. Wiesbaden: Steiner.

Haegen, H. Van Der (1995) Les Dynamiques de la Population, la Structure Socio-Spatiale et les Etrangers à Bruxelles. Paper presented at the conference on Ethnic Minorities and Social Duality in the Large Cities of Western Europe, Brussels.

Huttman, E. D., Blauw, W. and Saltman, J. (Eds) (1991) Urban Housing Segregation of Minorities in Western Europe and the United States. London: Duke University Press.

JACKSON, P. (Ed.) (1987) Race and Racism: Essays in Social Geography. London: Allen and Unwin.

KuiJsten, A. (1994) International migration in Europe: patterns and implications for receiving countries, in: International Migration: Regional Processes and Responses, United Nations Economic Commission for Europe, Economic Studies No. 7, pp. 21-40.

Lannoy, W. De (1975) Residential segregation of foreigners in Brussels, Bulletin, Société Belge des Etudes Géographiques, 44, pp. 215-238.

MAson, J. (1992) Taking the boat: women's emigration to London, Swansea Geographer, 29, pp. $65-77$.

PeACH, C. (1996) Does Britain have ghettos?, Transactions, Institute of British Geographers, 21, pp. 216-235.

Peach, C. and Byron, M. (1994) Council house sales, residualisation and Afro Caribbean tenants, Journal of Social Policy, 23, pp. 363383.

Robinson, V. (1993) Ethnic minorities and the enduring geography of settlement, Town and Country Planning, 62, pp. 53-56.

SALT, J. (1988) High-skilled migrants, careers and international labour markets, Geoforum, 19, pp. 387-399.

Sassen, S. (1991) The Global City: New York, London, Tokyo. Princeton, NJ: Princeton University Press.

Solomos, J. (1991) The politics of race and housing, Policy and Politics, 19, pp. 147-157.

StraubhaAR, T. (1992) Allocational and distributional aspects of future immigration to Western Europe, International Migration Review, 26, pp. 462-483.

Tijdschrift voor Economische en Sociale Geo- 
grafie (1997) Minorities in West-European Cities, theme issue, 88(2).

Waterman, S. and Kosmin, B. (1986) Mapping an unenumerated population: Jews in London, Ethnic and Racial Studies, 9, pp. 484-501.

Western, J. (1993) Ambivalent attachments to place in London: twelve Barbadian families, Environment and Planning D, 12, pp. 147-170.

White, P. (1984) The West European City: A Social Geography. London: Longman.

White, P. (1988) Skilled international migrants and urban structure in Western Europe, Geoforum, 19, pp. 411-422.
White, P. (1993) The social geography of immigrants in European cities: the geography of arrival, in: R. KING (Ed.) The New Geography of European Migrations, pp.47-66. London: Belhaven.

Zielke, E. (1982) Die Japaner in Düsseldorf: Manager-Mobilität-Voraussetzungen und Folgen eines Types Internationaler Geographischer Mobilität. Düsseldorfer Geographischer Schriften, 19. 
Copyright of Urban Studies is the property of Carfax Publishing Company and its content may not be copied or emailed to multiple sites or posted to a listserv without the copyright holder's express written permission. However, users may print, download, or email articles for individual use. 